\title{
Regarding Requirements for the Design and Installation of Elements for Passive Safety of Passenger Trains Operated by the Bulgarian State Railways
}

Mag. Eng. Venelin Pavlov ${ }^{1}$

${ }^{1}$ Machinery and Construction Technologies in Transport/Transport Equipment, Todor Kableshkov University of Transport, Sofia (Bulgaria)

When designing a new generation passenger train, it is necessary to provide for the existence of a passive safety system (PSS) integrated in its construction, which should ensure the protection of passengers and service personnel in the event of the most probable emergency collisions. The article provides an excerpt from statistics of accidents and incidents related to railway transport for the Bulgarian State Railways, which show the need to improve safety. The aim of the study is to develop energy absorption devices included in the PSS of high-speed passenger trains of a new generation. The article discusses the requirements for the harmonization of European safety standards and regulations in force in Russia and the United States. The main concepts of passive safety equipment and possibilities for application in the construction of passenger trains in operation of the Bulgarian State Railways (Holding BDZ EAD - BDZ - Passenger Transport EOOD) are indicated.

Key words: Railway stock, passenger trains, passive safety.

\section{INTRODUCTION}

In 1991 the UIC made appropriate adjustments in Leaflet 526 to comply with the new trends in railway transport and ensure traffic safety $[1,2,3]$. The most important change is aimed at increasing the energy absorption of draw gear equipment. Its minimum value is recommended to be $30 \mathrm{~kJ}$, which is a double increase of current standards.

The compressive forces are absorbed by buffers, which also maintain a certain distance between wagons [4]. The requirements for the structure of buffers are reflected in UIC Leaflets 526-1; 526-2 and 526-3.

The development of transport industry is always associated with accidents. The causes of accidents are many, including damage or breakage of parts, physical and moral aging of equipment, human factor, track poor condition, unfavourable weather conditions.

If we take into account the statistics of accidents, then it will be possible to trace a trend - the higher the speed, the more accidents happen in different modes of transport. Rail transport is no exception.

Since the managment teams of railway companies have set a goal to increase the volume of high-speed transport by $20 \%$ by 2030 , it is necessary to urgently improve the level of freight and passenger rail tran sport safety, especially of high-speed trains. Table 1 and Fig. 1 provide an excerpt of statistics of accidents and incidents [5] related to railway transport carried out by BDZ EOOD that shows the need to increase its safety.

The largest value of relative share of:

- collisions between trains in relation to the total number of accidents is $10 \%$ in 2019 ;

- collisions with a car at level crossings is $23.4 \%$ in 2017 ;

- all collision-related accidents are $92.9 \%$ in 2018 .
In order to reduce railway accidents, it is necessary to improve the two main safety systems:

- active safety system;

- passive safety system.

The main focus should be put on improving the passive safety system, which consists of developing a set of measures and technical solutions aimed at reducing the level of injuries caused to passengers and minimizing the damage to rail stock in cases where it is not possible to avoid collisions with obstacles.

Table 1 Collision-related accidents.

\begin{tabular}{|c|c|c|c|c|c|}
\hline Year & $\begin{array}{c}\text { Number } \\
\text { of } \\
\text { collisions } \\
\text { between } \\
\text { trains }\end{array}$ & $\begin{array}{c}\text { Number of } \\
\text { collisions } \\
\text { with cars at } \\
\text { level } \\
\text { crossings }\end{array}$ & $\begin{array}{c}\text { Number } \\
\text { of } \\
\text { collisions } \\
\text { with } \\
\text { people }\end{array}$ & $\begin{array}{c}\text { Total } \\
\text { number } \\
\text { of } \\
\text { colli- } \\
\text { sions }\end{array}$ & $\begin{array}{c}\text { Total } \\
\text { number } \\
\text { of } \\
\text { accidents }\end{array}$ \\
\hline 2015 & 3 & 6 & 33 & 42 & 48 \\
\hline 2016 & 3 & 5 & 24 & 32 & 40 \\
\hline 2017 & 1 & 11 & 29 & 41 & 47 \\
\hline 2018 & 1 & 5 & 33 & 39 & 42 \\
\hline 2019 & 4 & 7 & 24 & 35 & 40 \\
\hline
\end{tabular}

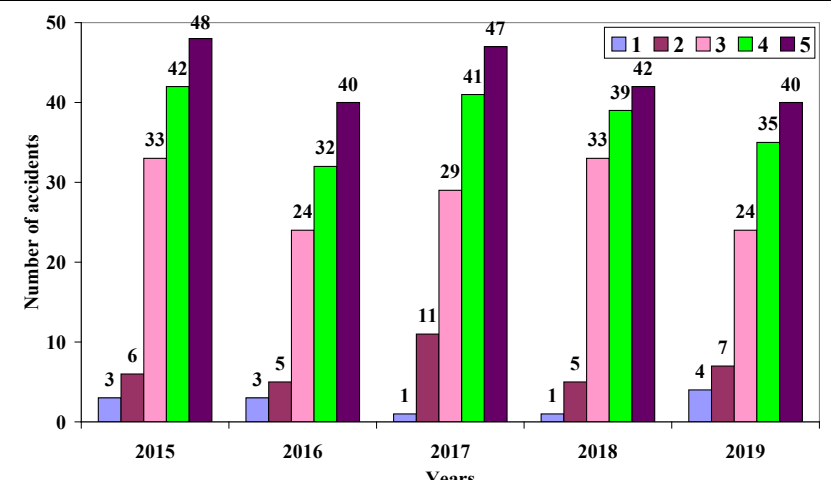


1 - Collision of a train with railway vehicle; 2 - Collisions with a car at railway crossings; 3 - Accident with people; 4 - Total collisions; 5 - Total accidents.

\section{Figure 1-Diagram of railway stock accidents related to} collisions.

Since the beginning of the $21^{\text {st }}$ century, global manufacturers of railway vehicles have begun to use passive safety elements in their projects, including emergency crash systems. In principle, they are similar to those used in cars but are adapted to the rail track conditions.

Crash emergency systems are designed to reduce the risk of severe accidents, injuries of passengers and train staff as well as to protect the load-bearing parts of wagon structure in case of train collision with an obstacle, particularly with another train. In this case the abs orption of kinetic energy is due to irreversible controlled deformation of crash elements.

Modern passive safety systems are based on a number of international research programs. As a result passive safety requirements have been proposed for all types of rolling stock, including urban rail vehicles. The requirements for emergency systems have been included in European standard EN 15227 [6].

It is increasingly necessary to introduce emergency crash elements in the structure of rail vehicle to provide protection against serious accidents, such as the accident in Hitrino in 2016 [5]. As a result of train derailment, the tank of the tenth tank wagon was drilled, which caused leakage of transported cargo (propylene) that subsequently ignited. The explosion and followed by fire killed 7 and seriously injured 29 residents of the village of Hitrino. The blast affected an area of about $535,000 \mathrm{~m}^{2}$, partially destroying 50 residential and public buildings, the railway infrastructure and rolling stock.

As a result of the investigation carried out, the Special Unit for Investigation of Accidents and Incidents in Railway Transport with Ministry of Transport, Information Technology and Communications prepared "Final Report on Technical Investigation of the Railway Accident" giving the following recommendation to prevent accidents cause by the same reasons: Tank cars transporting liquefied hydrocarbons have to be equipped with draw gear with crash elements according to the requirements of BDS EN 15227: $2008+\mathrm{A} 1$ : 2010 and shall possess a safety certificate.

\section{OVERVIEW OF THE REGULATORY REQUIREMENTS FOR RAILWAY STOCK EMERGENCY CRASH SYSTEMS}

In 1997 SAFETRAIN (Safe Train), a research project for railway safety, was launched in Europe [7], involving more than 10 European railway companies and rolling stock manufacturers such as Deutsche Balm, SNCF, Alstom, Siemens, Bombardier, etc. [8]. A great number of studies on vehicle passive safety were conducted under the project including human behaviour modelling in the event of train collision, nonlinear dynamic analysis of rail vehicle structure through the finite element method and field tests on rail vehicle collision.

The research results have contributed to the development of a regulatory document for ensuring passive safety of railways: EN 15227:2020 "Railway applications. Crashworthiness requirements for rail vehicles". In accordance with the principles of passive safety included in EN 15227, the emergency crash sy stem have to limit the acceleration of rail vehicles, ensure the integrity of the body structure in the passenger area and reduce the derailment risk of rail vehicles.

It is not possible to provide absolute protection to people in all possible cases of collisions, therefore the regulatory documents introduce the concept of an emergency collision scenario as a specific design case where the fulfilment of emergency crash system requirements are monitored. The collision scenarios were developed using the data taken from investigations of 500 accidents in 12 railway companies in Europe from 1991 to 1995. The data analysis made it possible to determine the most common cases of collisions of railway stock according to "Railway applications. Crashworthiness requirements for rail vehicles". Thus, when checking the requirements to crash system of a train running in regional European railway networks, it is necessary to use the following collision scenarios: head-on collision with identical rolling stock, collision with a freight wagon and collision with a freight vehicle at a level crossing.

According to the requirements of standard EN 15227 , the crash system efficiency is evaluated by the following criteria:

- by the values of rolling stock longitudinal accelerations; - by the values of the residual deformation of rolling sto ck body;

- by the condition wheel-rail contact maintenance (for assessment of derailment risk).

Comparing the basic provisions of EN 15227 with GOST 32410-2013 "Emergency systems for emergency rolling stock for passenger transport. Technical requirements and control methods" [9], it can be noticed that the Russian standard is not equivalent to the European one because of the differences in railway stock structure and in the statistics of collision accidents in the CIS countries and the European Union. The performance of the crash system in this standard is checked by the values of rolling stock longitudinal accelerations and the values of the residual deformations of car bodies, without checking the maintenance condition of wheel-rail contact. Similar to the European standard, the control on fulfilment of emergency crash system requirements is carried out according to the design scenarios: emergency collision with a car at a level crossing and collision with a freight wagon.

Analyzing the existing differences in the conditions of collision scenarios, the following can be distinguished:

- GOST 32410-2013 does not have a scenario of collision with identical rolling stock;

- in the collision scenario established by EN15227 the freight wagon has buffers with a given energy absorption while according to GOST 32410 the freight wagon shall not be equipped with buffers as they do not exist in the wagons operated in Russia;

- in European standard EN15227 the scenario of collision with a car provides irreversible obstacle deformation while according to GOST 32410-2013 the obstacle is given as an absolutely rigid body. 
Table 2 presents a comparison of crash scenarios.

Table 2 - Comparison of crash scenarios

\begin{tabular}{|c|c|c|c|}
\hline Scenarios & Scenario parameters & EN 15227-2008 [6] & GOST 32410-2013 [9] \\
\hline \multirow{6}{*}{ 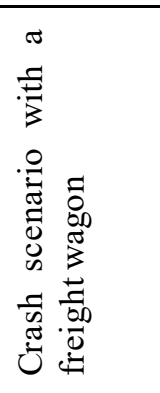 } & Crash speed & $36 \mathrm{~km} / \mathrm{h}$ & $36 \mathrm{~km} / \mathrm{h}$ \\
\hline & Obstacle mass & $80 \mathrm{t}$ & $80 \mathrm{t}$ \\
\hline & Obstacle geometry & 2850 & 3200 \\
\hline & & ل1 & 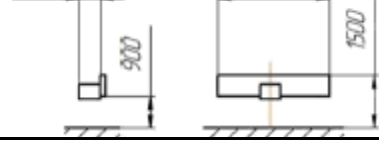 \\
\hline & Obstacle stiffness & Absolutely solid body* & Absolutely solid body \\
\hline & $\begin{array}{l}\text { Acceleration limit per unit of } \\
\text { rail vehicle }\end{array}$ & $5 \mathrm{~g} * *$ & $50 \mathrm{~m} / \mathrm{s}^{2}$ \\
\hline \multirow{5}{*}{ 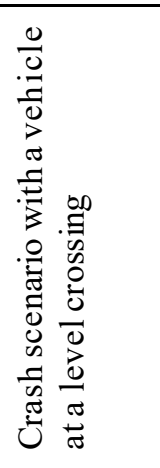 } & Crash speed & $110 \mathrm{~km} / \mathrm{h}$ & $72 \mathrm{~km} / \mathrm{h}(110 \mathrm{~km} / \mathrm{h})^{* * *}$ \\
\hline & Obstacle mass & $15 \mathrm{t}$ & $10 \mathrm{t}$ \\
\hline & Obstacle geometry & $\sqrt[2]{(-1-17}$ & 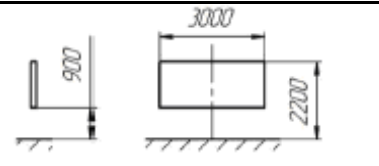 \\
\hline & Obstacle stiffness & \begin{tabular}{l|lll} 
& & \\
1 & & & \\
0 & 0,5 & 1,0 & 1,5
\end{tabular} & Absolutely solid body \\
\hline & $\begin{array}{l}\text { Acceleration limit per unit of } \\
\text { rail vehicle }\end{array}$ & $7,5 \mathrm{~g}$ & $50 \mathrm{~m} / \mathrm{s}^{2}$ \\
\hline
\end{tabular}

* - in the freight car collision scenario. EN 15227 defines the power features of buffer devices whose total energy capacity is $62 \mathrm{~kJ}$;

** - g - ground acceleration;

*** - a collision speed of $110 \mathrm{~km} / \mathrm{h}$ is set for a vehicle with a design speed over $160 \mathrm{~km} / \mathrm{h}$.

The collision scenario with a car in GOST 32410-

2013 is of particular interest because the obstacle is assumed as an absolutely rigid body.
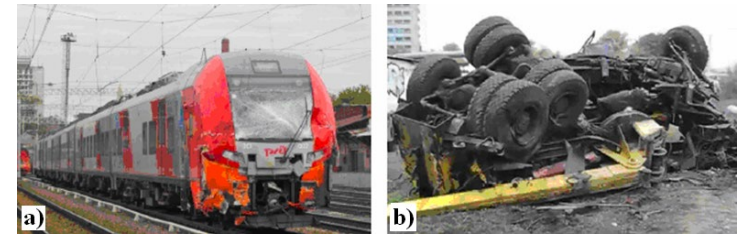

a) - damage to the electric train; b) - damage to the car.

Figure 2 - Consequences of the emergency collision of "Swallow" electric train

Under real conditions, the car has a relatively low strength, therefore in a collision it will suffer significant damage and thus will affect the processes of accident. This is confirmed by the collision of "Swallow" electric train at a speed of $90 \mathrm{~km} \mathrm{~h}$ with an MAZ car [10]. The consequences of this collision are shown in Fig. 2.

This collision corresponds to the conditions of a collision scenario with a truck: the collision speed and the mass of obstacle were identical to the design conditions: the check of electric train damage revealed that the emergency energy absorption device of the emergency system had not worked because there were no residual deformations, while at the same time the first bogie derailed.

Thus, in a real emergency situation, the car absorbed part of the energy of collision due to its own destruction. At the same time to model a car in the form of an absolutely rigid body does not allow to take into account this effect that can lead to a strong discrepancy between the calculation results and the actual consequences of collision.

On November 12, 2019, 19205 passenger train (PT) consisting of an electric multiple unit (EMU) series 31$005 / 006$ with four wagons was moving in direction Plovdiv - Asenovgrad - Plovdiv. At 06:42 the traffic manager on duty at Krumovo station ordered the departure of 19205 passenger train (PT) with a telephone message to the guards of the level crossings at kilometer $3^{+784}$ and at kilometer $8^{+830}$. After the train left Krumovo station at $06: 44$, the on-duty traffic manager verbally informed the level-crossing guards about the train departure. Although the guard of level-crossing at $\mathrm{km} 8^{+830}$ had recorded the telephone message, he did not activate the barrier mechanisms before passing of 9205 passenger train. Approaching the level crossing, the engine driver gave a "Warning" signal with the whistle of the EMU having seen that the barriers are raised and the crossing guard is standing next to the barrier control mechanism. At that moment, a vehicle - an Opel (ASTRA) car, approached the level crossing to the left in direction of the train running and entered the danger zone [11]. That resulted in a collision, the car was turned and thrown to the left of railway track and the train continued to run without stopping.

One of the passengers travelling next to the driver died. The engine driver was not injured. The left side of the EMU was damaged (Fig. 3a) and severe damage was inflicted to the car (Fig. 3b). 


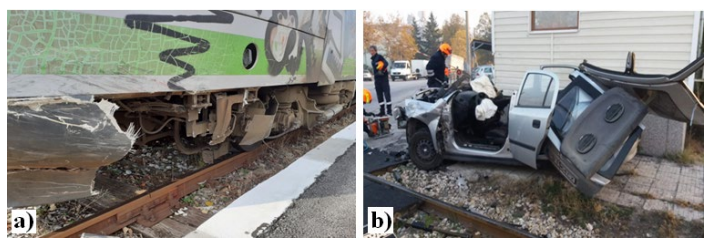

a)-damage caused to the EMU; b) -damage caused to the car.

Figure 3 - Consequences of the emergency collision of an EMU with a car at a level crossing [11].

It is not only in the European countries, but also in the United States experts have been actively involved in the passive safety issues in railway transport for more than 20 years, so a significant number of different designs of energy-absorbing devices have been already available. That is why regulatory documents have appeared and based on them modern public standards have been developed. Both Western European and US regulatory agencies are making significant efforts to rapidly update rail stock safety requirements. The modern rail stock operating on the European railways shall meet the following standards EN 12663: 2000 [12] and EN 15227: 2008; in the United States railways shall keep the Code of Federal Regulation 49 CFR [13].

In terms of harmonization, European standard EN 15227 is closer to the safety standards, which are in force in Russia. The development of TT SPB and GOST $32410-$ 2013 has taken into account the peculiarities of rail stock (structure, design, production, testing, operation) in Russia, as well as statistics of rail stock emergency collisions with obstacles that differ from the European ones. Tables 3 and 4 show the main differences between the European, American and Russian standards [14].

Table 3 -Maximum values of accelerations in strength calculations of wagon equipment and interior

\begin{tabular}{|l|c|c|c|c|}
\hline \multirow{2}{*}{ Standard } & \multicolumn{4}{|c|}{ Acceleration values by axes } \\
\cline { 2 - 5 } & $\begin{array}{c}\mathrm{X} \\
\text { (longitu- } \\
\text { dinally) }\end{array}$ & $\begin{array}{c}\text { Y } \\
\text { (verti- } \\
\text { cally) }\end{array}$ & $\begin{array}{c}\text { Z (transversally) to the } \\
\text { body }\end{array}$ \\
\cline { 3 - 5 } & & $\begin{array}{c}\text { In the } \\
\text { front part }\end{array}$ & $\begin{array}{c}\text { In the } \\
\text { middle part }\end{array}$ \\
\hline $\begin{array}{l}\text { EN 12663, } \\
15227\end{array}$ & $\pm 5 \mathrm{~g}$ & $\pm 1 \mathrm{~g}$ & $\pm 3 \mathrm{~g}$ & $\pm 1,5 \mathrm{~g}$ \\
\hline 49CFR & $\pm 8 \mathrm{~g}$ & $\pm 4 \mathrm{~g}$ & \multicolumn{2}{|c|}{ $\pm 4 \mathrm{~g}$} \\
\hline TT SPB & $\pm 7,5 \mathrm{~g}$ & $\pm 1 \mathrm{~g}$ & $\pm 3 \mathrm{~g}$ & $\pm 1,5 \mathrm{~g}$ \\
\hline $\begin{array}{l}\text { Gost 32410- } \\
2013\end{array}$ & $\pm 5 \mathrm{~g}$ & $*$ & \multicolumn{3}{|c}{$*$} \\
\hline
\end{tabular}

* It is not regulated

Table 4-Main crash scenarios of wagons and locomotives

\begin{tabular}{|c|c|c|c|c|c|c|c|}
\hline \multirow{2}{*}{$\begin{array}{c}\text { Speed V, } \\
\mathrm{km} / \mathrm{h}\end{array}$} & \multicolumn{7}{|c|}{ Crash scenarios } \\
\hline & No1 & No 2 & No & & $\mathrm{No}$ & & No5 \\
\hline $\begin{array}{l}\text { EN 12663, } \\
15227\end{array}$ & 36 & 36 & - & & 110 & & - \\
\hline TT SPB & - & - & 18 & 36 & - & 72 & 110 \\
\hline $\begin{array}{ll}\text { Gost } 32410- \\
2013\end{array}$ & - & - & 36 & - & 72 & & 110 \\
\hline
\end{tabular}

No 1 - collision with an identical train; No 2 - with a freight wagon of 80 t equipped with buffers; No 3 - with freight wagon with mass $80 \mathrm{t}$ without buffers; No 4 - with a freight vehicle (truck) with a mass of $15 \mathrm{t}$; No 5 - with a freight vehicle (truck) with a mass of $10 \mathrm{t}$.
The mentioned distinctive features of main regulatory documents setting the requirements for passive protective devices show that the existing collision scenarios do not fully take into account all possible cases of emergency collisions.

Based on the statistics of railway accidents and the operating conditions of rail stock, it is necessary to significantly expand the list of possible collision scenarios.

In order to fully cover all possible collision scenarios, based on statistics, the main types of obstacles must be taken as follows:

- obstacle No 1 - a large animal with a mass of $1 \mathrm{t}$;

- obstacle No 2 - a vehicle with mass of 2 t;

- obstacle No 3 - a truck with mass of $15 \mathrm{t}$;

- obstacle No 4 - a heavy truck of $30 \mathrm{t}$;

- obstacle No 5 - a freight wagon of $80 \mathrm{t}$ without buffers;

- obstacle No 6 - a similar fixed train with different mass.

The study of emergency collisions with the indicated types of obstacles will allow to determine the area of effective operation of energy absorption devices (EOD) and to design energy-absorbing structures that meet the requirements of regulations.

\section{COLLISION SCENARIOS}

Collision scenarios have been developed taking into account statistical analyzes of railway accidents in Europe and the CIS [14].

Collision scenarios (Fig. $4 \div 7$ ) are characterized by a set of conditions for emergency collision of passenger cars/trains with an obstacle (values of masses, initial speeds and other parameters of the objects of collision). relative speed $\ldots \rightarrow \ldots 36 \mathrm{~km} / \mathrm{h}$

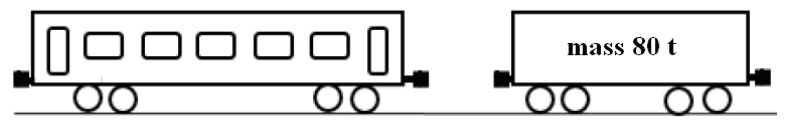

Figure 4: Collision scenario $(4 a, 4 b)$ of a passenger car equipped with side buffers for $1435 \mathrm{~mm}$ gauge
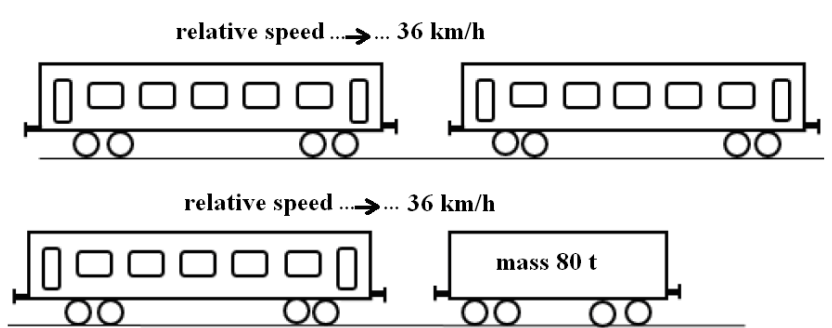

On a track gauge of $1520 \mathrm{~mm}$ - a collision at a speed of $36 \mathrm{~km} \mathrm{~h}$ with a freight wagon of $80 \mathrm{t}$.

Figure 5: Collision scenario of a passenger carriage equipped with auto-coupler for $1520 \mathrm{~mm}$ track gauge
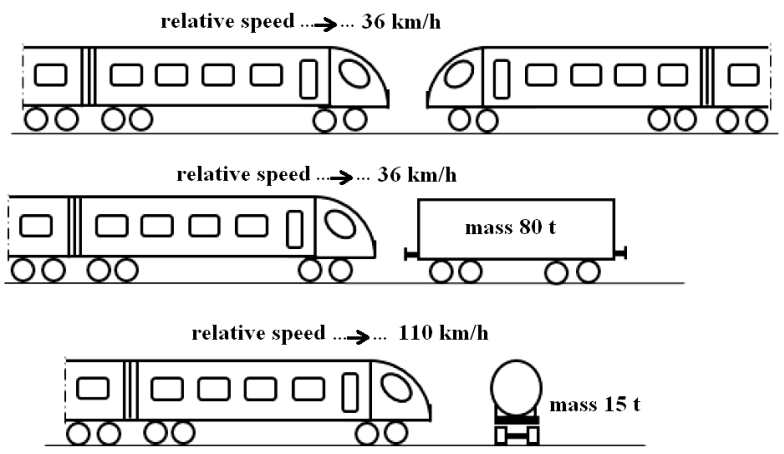

Figure 6: Collision scenario $(1 a, 1 b, 2)$ of a multiple unit equipped with auto-couplerfor 1435 mm track gauge 


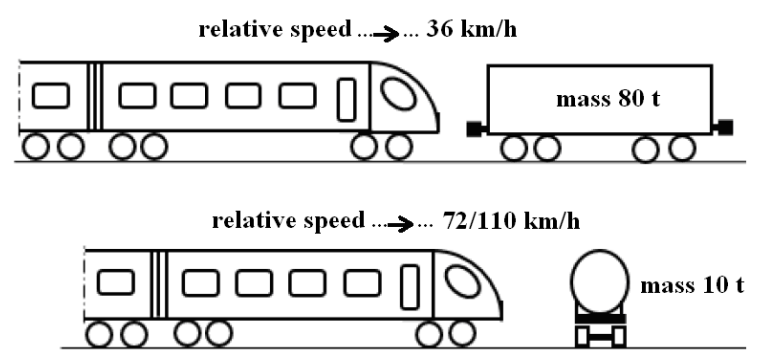

Figure 7: Collision scenario $(1 \mathrm{~b}, 2)$ of a multiple rail unit equipped with auto coupling for $1520 \mathrm{~mm}$ track gauge

To determine the power and energy features of the crash system devices, the following collision scenarios have been assumed:

- scenario 1 a simulates an emergency collision of with passenger cars/trains of one and the same type (only for $1435 \mathrm{~mm}$ gauge track);

- scenario $1 \mathrm{~b}$ simulates an emergency collision with a freight wagon of $80 \mathrm{t}$;

- scenario 2 simulates an emergency collision at a level crossing with a vehicle of $15 \mathrm{t}$ for a track gauge of $1435 \mathrm{~mm}$ and of $10 \mathrm{t}$ for a track gauge of $1520 \mathrm{~mm}$.

The following collision scenarios are foreseen for passenger carriages with locomotive traction:

On a track gauge of $1435 \mathrm{~mm}$ :

- collision at a speed of $36 \mathrm{~km} / \mathrm{h}$ with the same type of passenger cars;

- a collision at a speed of $36 \mathrm{~km} / \mathrm{h}$ with a freight wagon of 80 t equipped with a side buffer set.

The following collision scenarios are provided multiple units (connected trains).

For track gauge of $1435 \mathrm{~mm}$ :

- collision at a speed of $36 \mathrm{~km} / \mathrm{h}$ with a train of the same type;

- collision at a speed of $36 \mathrm{~km} / \mathrm{h}$ with a freight wagon of 80 t equipped with a side buffer set;

- collision with a speed of $110 \mathrm{~km} / \mathrm{h}$ at a level crossing with a truck weighing $15 \mathrm{t}$.

For track gauge of $1520 \mathrm{~mm}$ :

- collision at a speed of $36 \mathrm{~km} / \mathrm{h}$ with a freight wagon of $80 \mathrm{t}$;

- a collision at a speed of $72 \mathrm{~km} / \mathrm{h}$ at a level crossing with a vehicle weighing $10 \mathrm{t}$ at a design train speed not exceeding $160 \mathrm{~km} / \mathrm{h}$;

- collision at a speed of $110 \mathrm{~km} / \mathrm{h}$ at a level crossing with a vehicle weighing $10 \mathrm{t}$ at a design train speed exceeding $160 \mathrm{~km} / \mathrm{h}$.

\section{TESTS OF PASSENGER CARRIAGES UNDER COLLISION SCENARIOS}

The passenger carriages participate in collision scenarios in a reference train, which includes a locomotive and four passenger carriages of one and the same structure.

A four-axle locomotive with an axle load of $19 \mathrm{t}$, having a rigid (non-deformable) body, equipped with a auto-coupler with a locking contour in compliance with GOST 21447 [15] and absorbers of T2 class with energy absorption from $100 \mathrm{~kJ}$ at a full stroke of $120 \mathrm{~mm}$ in compliance with GOST 32913 [16], equipped with crash elements in the front locomotive parts.

The crash elements of this locomotive must provide an average value of its longitudinal acceleration equal to the absolute value of $50 \mathrm{~m} / \mathrm{s}^{2}$ in emergency collision with an obstacle of the locomotive without wagons in a collision scenario 1 .

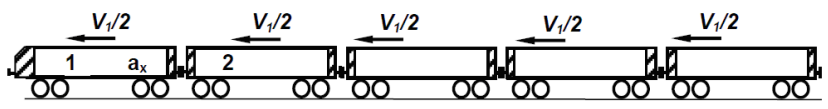

- crash elements in locomotives and wagons fronts.

Figure 8: Reference train composition for testing passenger carriages.

where: 1 - front unit of the train (locomotive), 2 - a passenger carriages under evaluation, $a_{x}$ is the amount of delay in the longitudinal direction of the leading train unit; $\mathrm{a}_{\mathrm{x}}=5,0 \mathrm{~g}$ according to point 7.1 of GOST $32410-2013$ or point 6.4 of EN $15227, \mathrm{~V}_{1} / 2$ - half of the collision speed according to scenario 1 .

While testing a multiple unit, the composition shown in Fig. 9 is used. In the case of operation of fewer wagons, tests with the same minimum train composition are admitted.

The minimum number of wagons in the train is 1 wagon (e.g. a rail bus), but the abovewritten does not exclude such a case.

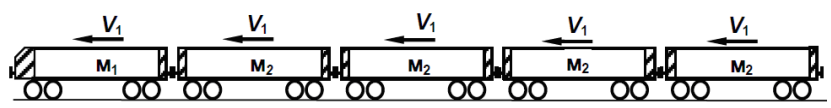

- crash elements at the front of the wagons.

Figure 9: Testing of multiple unit rail stock.

where: $M_{1}$ is the mass of a multiple unit wagon; $M_{2}$ is the average mass of an intermediate wagon.

In order to clarify the state of force factors in the collision of two vehicles and to be able to specify the efficiency of the energy-absorbing elements, it is necessary to analyze relative movement of the two vehicles, which subsequently interact with their draw gear equipment.

Using the Lagrange equation and taking into account the kinetic energy and the total system energy absorption, an equation is obtained, which determines the maximum value of impact force from collision between two vehicles [17]:

$$
\mathrm{F}=\sqrt{2\left((2 \mathrm{i})^{-1} \cdot \mathrm{M} \cdot \mathrm{V}_{0}{ }^{2}-\mathrm{E}_{0}\right) \cdot \mathrm{k}}
$$

where: $\mathrm{F}$ - force acting on the buffers;

$M$ - reduced mass; $M=\left(m_{1} \cdot m_{2}\right) /\left(m_{1}+m_{2}\right)$, where $m_{1}, m_{2}$ masses of the first and second vehicles; E - energy absorption of the buffers; $\mathrm{k}$ - stiffness of the wagon structure; i - coefficient obtained from experimental data and reflecting the inertial characteristic of the system under the conditions of impact, taking into account the influence of spring suspension, the shocking wagons and track superstructure of the railway, the energy absorption of load, etc.

Analyzing the formula given above and taking in to account the high value of wagon structure stiffness; we can see the crucial importance of energy absorption of buffers to prevent impact forces of inadmissible values.

\section{OVERVIEW OF STRUCTURAL fEATURES OF "CRASH" ENERGY ABSORPTION DEVICES}

Thin-walled metal tubes are widely used to manufacture energy absorption devices. The absorption features of tubes are influenced by the type of metal, 
geometric parameters and given deformation mode. The following deformation modes can be distinguished for thin-walled metal tubes:

- axial deformation. The deformation mode is characterized with load directed along the longitudinal axis of the tube that leads to a local plastic loss of stability of the tube walls with formation of annular folds;

- transverse deformation. The pressure load in this mode of deformation is perpendicularly directed to the tube longitudinal axis;

- deformation with inversion of walls. In this mode, energy is absorbed when the tube is pressed into a punch with a special shape, which leads to radial plastic deformation and inversion of tube walls;

- deformation with expansion of walls. The deformation mode is carried out by pressing the "sacrifice" tube into a harder tube with a conical contact surface, while the energy is being absorbed due to radial plastic deformation and due to friction on the walls of tubes;

- deformation with tearing the walls of tubes. The deformation mode is accompanied by the formation of multiple longitudinal cracks along the deformed tube and the accompanying division of its wall into strips.

Based on the analysis of references $[18,19]$, Table

5 shows the energy absorption features of steel tubes depending on deformation modes.

Table 5-Energy absorption features for steel tubes depending on deformation modes

\begin{tabular}{|l|l|l|l|l|l|}
\hline $\begin{array}{l}\text { Features } \\
\text { of energy } \\
\text { absorption }\end{array}$ & $\begin{array}{l}\text { Axial } \\
\text { defor- } \\
\text { mation }\end{array}$ & $\begin{array}{l}\text { Transverse } \\
\text { defor- } \\
\text { mation }\end{array}$ & $\begin{array}{l}\text { Inver- } \\
\text { sion of } \\
\text { walls }\end{array}$ & $\begin{array}{l}\text { Widen- } \\
\text { ing } \\
\text { walls }\end{array}$ & $\begin{array}{l}\text { Tearing } \\
\text { walls }\end{array}$ \\
\hline $\mathrm{CF}$ & 0,3 & 0,9 & 0,8 & 0,8 & 0,6 \\
\hline $\begin{array}{l}\mathrm{SE}, \\
\mathrm{kJ} / \mathrm{kg}\end{array}$ & $8 \div 30$ & $2 \div 8$ & $6 \div 12$ & $9 \div 24$ & $6 \div 20$ \\
\hline
\end{tabular}

Table 6 shows a comparison of deformation modes according to load patterns, deformation diagrams and forms of plastic deformation.

Table 6-Tube deformation modes

\begin{tabular}{|c|c|c|}
\hline Mode & $\begin{array}{l}\text { Deformation } \\
\text { form }\end{array}$ & Comment \\
\hline 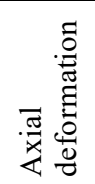 & & $\begin{array}{l}\text { Advantages: high energy } \\
\text { absorption. } \\
\text { Disadvantages: low coefficient of } \\
\text { deformation force; unstable } \\
\text { deformation force. }\end{array}$ \\
\hline 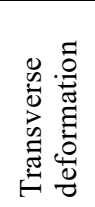 & & $\begin{array}{l}\text { Advantages: high coefficient of } \\
\text { deformation force; stable } \\
\text { deformation force } \\
\text { Disadvantages: low energy } \\
\text { absorption. }\end{array}$ \\
\hline 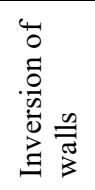 & & 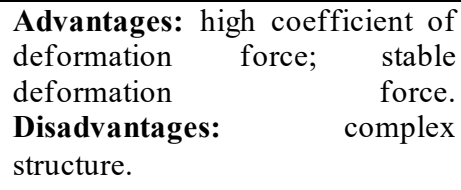 \\
\hline 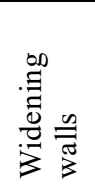 & & $\begin{array}{lr}\text { Advantages: } & \text { high coefficient of } \\
\text { deformation force; } & \text { stable } \\
\text { deformation } & \text { force. } \\
\text { Disadvantages: } & \text { complex } \\
\text { structure. } & \end{array}$ \\
\hline
\end{tabular}

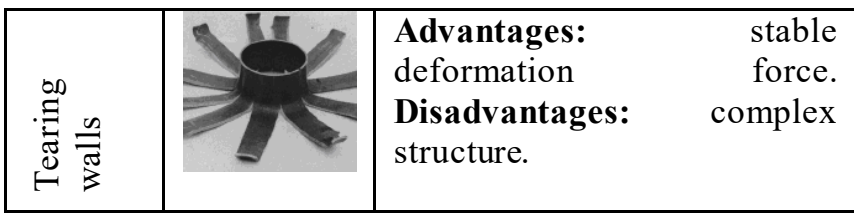

Energy absorbing devices are most often made of thin-walled metal structures that absorb energy by analogy with the axial deformation of tubes. Such devices have high energy absorption and very simple design but there are also disadvantages expressed in big triggering force and unstable axial deformation force.

In order to reduce the triggering force, it is necessary to reduce the local hardness of energy absorption device, e.g. by reducing the wall thickness in a certain area of device structure. Another method involves the development of an energy absorption device with inclination of its walls relative to the longitudinal ax is (in the form of a truncated pyramid) [18] as shown in Fig. 10a. It is also possible to reduce the trigforce by introducing special zones of stress concentration, particularly by creating perforations in the energy absorption device structure [19] as shown in Fig. 10-b.

Thick-walled tubes with belts in the form of wide cylinders on the outer surface possess good energy absorption features during axial deformation: as it is shown in Fig. 10-c, the thick sections provide stable destruction of the entire structure. As a result such transformation reduces the sensitivity to deviations in the angle of loading as well as to triggering force and stabilizes the axial deformation force.

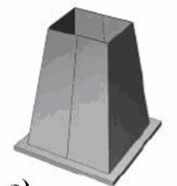

a)

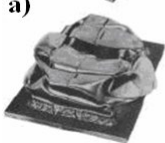

b)
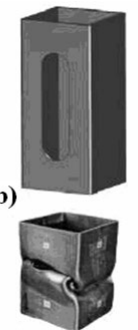

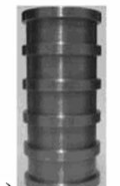

c)

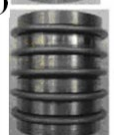

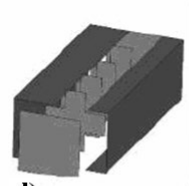

d)

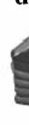

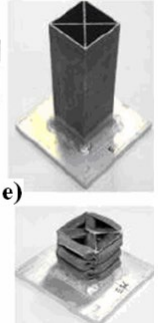

a) - design of sloping walls; b) -creation of perforations; c) creation of belts; (d) - introduction of diaphragms; e) introduction of auxiliary cells

Figure 10: Technical solutions for improving energy absorption features [18,19].

Another way to ensure a stable deformation force is to incorporate metal diaphragms into the energy absorption device as shown in Fig. 10-d [18,19]. It is possible to achieve an energy consumption increase of the energy absorption device with unchanged dimensions introducing auxiliary tube cellular energy capacity from 11.21 to $35.00 \mathrm{~kJ} / \mathrm{kg}$. An example of such structures is shown in Fig.10-e.
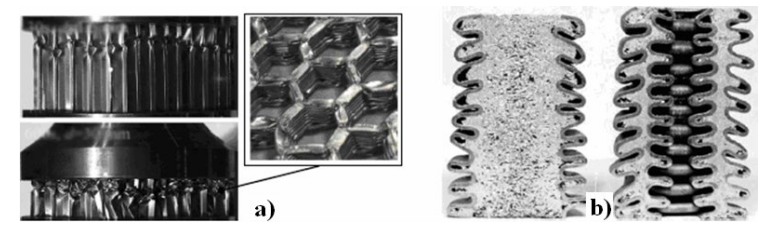

(a) honeycomb structures; b) metal tubes filled with aluminium foam

Figure 11: Energy absorber structural elements [18,19]

Honeycomb structures made of aluminium are an 
array structure of hollow cells formed of thin vertical walls (Fig. 11-a). They have good absorption features thanks to their high strength combined with small weight.

According to the study results, it was found that the absorption features of metal tubes filled with aluminium foam are influenced by the ratio between the wall thickness and the diameter of inscribed cell circle and the angle of branching of cells (Fig. 11-b).

Based on the review, a classification of technical solutions for improving the features of energy abs orption devices operating in axial deformation mode has been developed and presented in Fig. 12.

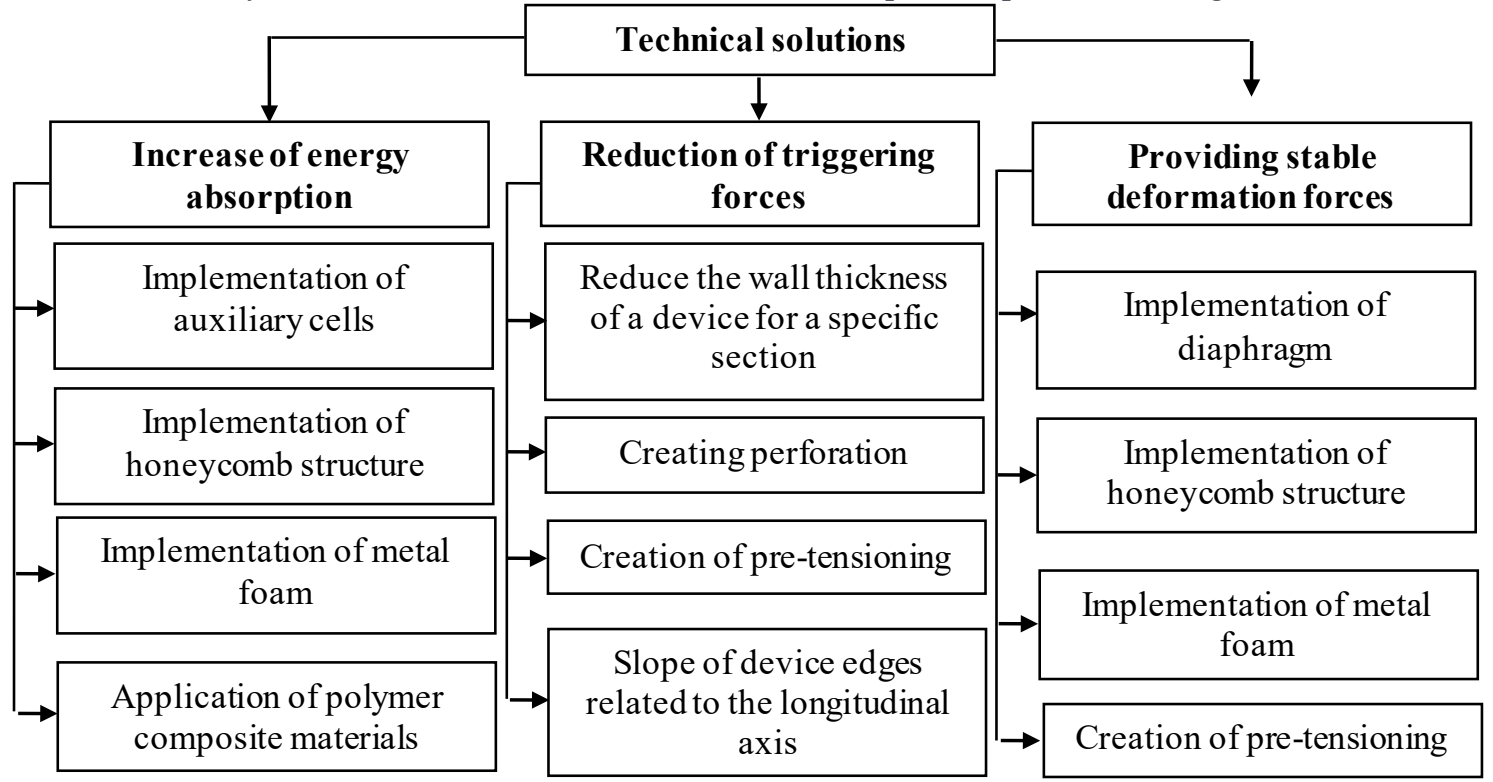

Figure 12: Technical solutions to improve the performance of energy absorbing devices.

\section{BUFFER STRUCTURES IN OPERATION OF BDZ HOLDING "PASSENGER TRANSPORT"}

The structures of buffers for passenger carriages in operation of BDZ holding "Passenger Transport" are buffers with metal-rubber absorbers and buffers with absorbers made of elastomeric or hydraulic capsules.

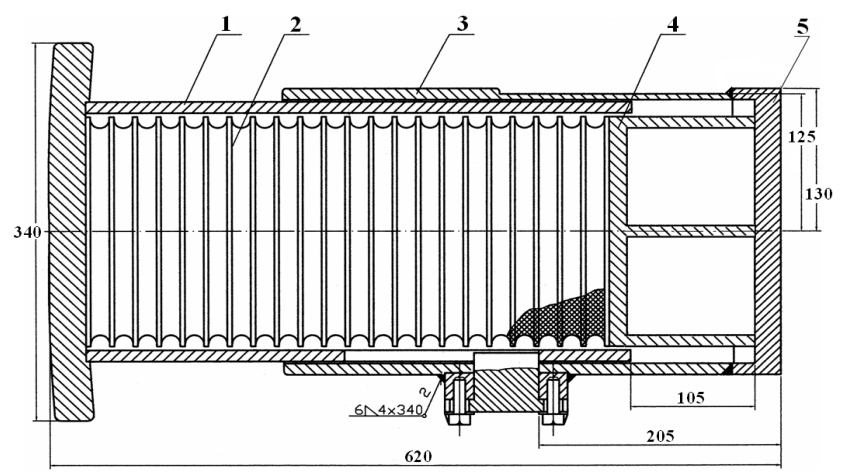

1-plate with a bushing; 2-rubber-metal package; 3-outer cylinder; 4 -support; 5-supporting plate.

Figure 13: Buffer with a metal-rubber package [20].

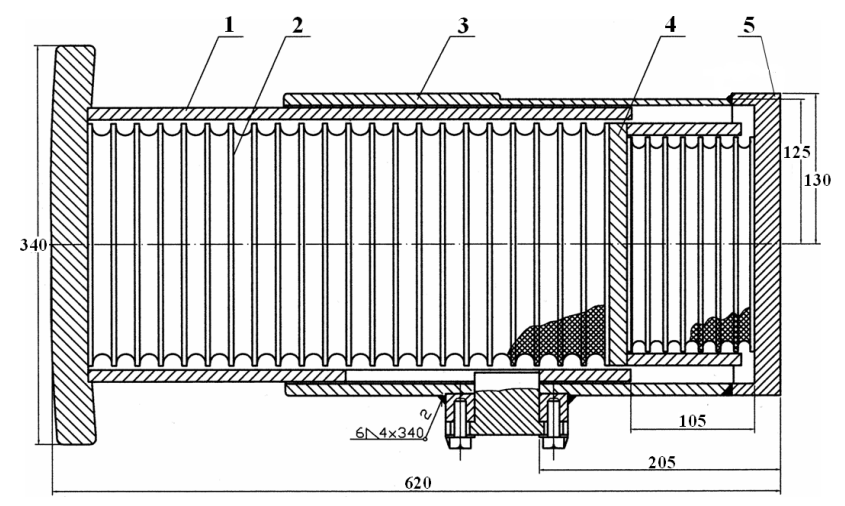

1-plate with a bushing; 2-rubber-metal package; 3-outer cylinder; 4-support with a metal-torsion plate; 5-supporting plate.

Fig. 14 Buffer with two metal-rubber packages [20].

At present the most widespread devices in the Bulgarian railways are draw gear ones based on rubbermetal packages (Fig.13 and Fig.14).

There are two types of buffers with rubber-metal packages used in operation. The older device is with a stroke of $105 \mathrm{~mm}$ and one rubber-metal package (Fig. 13). The latest buffer, which is with increased energy absorption and the same stroke of $105 \mathrm{~mm}$, has two rubber-metal packages: the smaller package is behind the bigger one (Fig. 14).

The elastic element in both types is a metal-rubber package made of metal plates and rubber discs, which are glued together by vulcanization.

The smaller rubber-metal package of buffer with increased energy absorption is placed on the rear part of support plate and it serves to absorb smaller forces during the train movement $(120 \div 150 \mathrm{kN})$; with the increase of force acting on the buffer, the bigger rubber-metal package is also included in energy absorption. In this way the power characteristic of buffer with increased energy absorption becomes softer than the one of the buffer produced with one bigger rubber package. In its turn that helps the vehicle to run at a higher speed in rail track curved sections.

These were the prerequisites that imposed the development of rubber-metal packages with high en ergy absorption at the Research Institute for Transport jointly with the Research Institute for Rubber and Plastics Industry.

The tests for establishing a suitable rubber composition for the rubber elements of rubber-metal packages for buffers were carried out on the basis of the 
rubber requirements in compliance with the approved methodology for conducting type tests as well as on the specific operating conditions under which rubber works.

Based on the abovementioned, the rubber for a metal package must have:

- Good resistance to thermal aging, expressed in changes of the basic strength indicators after 7 -day aging at $70^{\circ} \mathrm{C}$ within the range of up to $20 \%$ and hardness up to 10 units.

- Small residual deformation under pressure combined with high elasticity.

- Preservation of its qualities and performance at low temperatures.

To meet these requirements to rubber, which serves as an elastic element in buffers with rubber-metal packages, a recipe has been developed and adopted.

The use of elastomer SKD leads to a decrease of the abovementioned indicators but at the same time to a significant improvement of their elasticity and residual deformation under pressure.

The application of elastomer SKD up to $10 \%$ in the of natural rubber composition leads to a decrease of their brittleness temperature by $5^{\circ} \mathrm{C}$. The percentage changes of values of physicochemical parameters of vulcanizates in the mixtures under examination after thermal aging at $70^{\circ}$ $\mathrm{C}$ for $72 \mathrm{~h}, 168 \mathrm{~h}$ are very small and within the requirements. The obtained negative values for the change of tensile strength in some vulcanizates are due to the increase of this indicator after aging, which is characteristic of synthetic rubber. Based on the abovementioned, it follows that all tested rubber compositions have very good resistance to thermal aging. The small change in the hardness of vulcanizates after thermal aging of most tested compositions up to 2 units will have a favourable effect on the characteristics of buffer in the process of operation.

In general, the buffer with a rubber-metal package is tested in Research and Technology Institute of Railway Transport (НИТИЖТ) [2] - the first stage of the tests was intended to take down the static characteristics. The buffer was tested as a set, in the kind it would be mounted on the wagon for operation. The ambient temperature was $15^{\circ} \mathrm{C}$.

The buffer was loaded using a laboratory press at a speed not exceeding $0.05 \mathrm{~m} / \mathrm{s}$. The buffer was unloaded immediately after loading, continuously reporting about the deformation obtained.

The maximum force of $1000 \mathrm{kN}$ was obtained at a maximum deformation stroke of $105 \mathrm{~mm}$. The pretensioning was $\sim 20 \mathrm{kN}$.

The total energy absorption of buffer $\mathrm{We}=23500 \mathrm{~J}$, which is significantly higher than the determined limit of $12500 \mathrm{~J}$, the irreversible energy absorption $\mathrm{We}=12500 \mathrm{~J}$, which represents $53 \%$.

There are also strength requirements to buffers, as they are subjected to axial loading with force $\mathrm{F}>2500 \mathrm{kN}$ and transverse force $F_{2}>200 \mathrm{kN}$ ( $F_{2}$ is applied to the buffer casing).

It was found that the buffer continues to function normally, with no residual deformations. Also, no residual deformations were found after loading the support plate with a force of $2500 \mathrm{kN}$. It should be noted that regulations allow residual deformations after loading, commensurable with the established deviations in dimensions during their production, which should not be greater than $0.2 \%$.

The buffer dynamic tests were performed on an crash test bench at different speeds. The maximum energy absorption of $30 \mathrm{~kJ}$ was obtained at a maximum force of $1000 \mathrm{kN}$.

Conclusion: Buffers with metal-rubber GUMMETSL packages are a relatively reasonable compromise between cost and efficiency of draw gear. With maximum use of the bushing internal space and the correct choice of rubber mixture, it is possible to implement a buffer that meets the requirements of UIC Leaflet 526-1 and UIC Leaflet 528 [22].

Their main advantages are relatively low price and satisfactory reliability. In addition, these buffers have a number of disadvantages, the most important of which are:

1. Accumulated and especially absorbed energy have small values. According to these indicators, they are on the border of what is allowed by the UIC, which calls into question their efficiency and possibility to perform domestic and especially international transport. The metalrubber package qualities are extremely dependent on the composition of rubber mixture and manufacturing technology. Even small deviations from the established recipe or production technology lead to significant differences in the buffer strength features. This is the main reason why it cannot be claimed that the Bulgarian freight wagons are equipped with draw gear corresponding to Leaflet 526-1 and Leaflet 528.

3. The buffers with rubber-metal packages (RMP) have a relatively low durability, which is incommensurable with the durability of the wagon body. The main reason for this is aging of rubber due to oxidation and variable temperatures during operation.

4. This type of elastic elements have a nonlinear parabolically increasing characteristic. Therefore, at the end of stroke the force acting on the buffer is approximately equal to the maximum admissible for both the draw gear and wagon metal body.

This leads to extremely unfavorable consequences related to the strength of front beam and other loadbearing elements, the safety of cargo or comfort of passengers in passenger cars.

The elastomeric buffers in Fig. 15 most often consist of metal part and a set of two energy absorption elements.

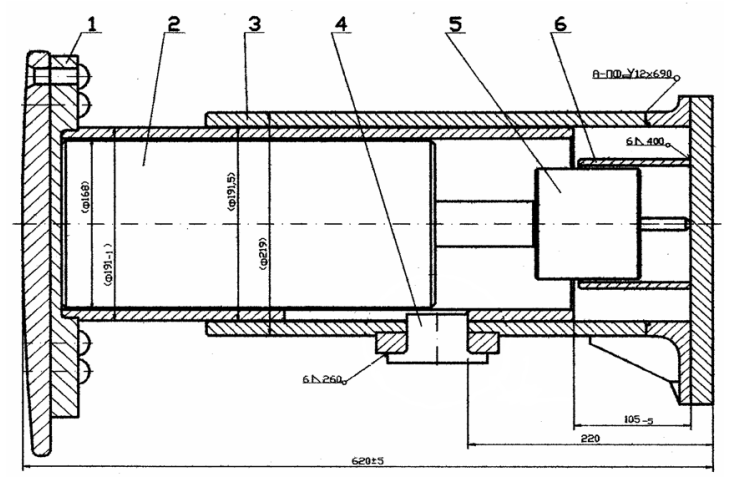

1 - plate; 2 - large elastomeric capsule; 3 - outer cylinder; 4 trigger; 5 -small elastomeric capsule; 6 -guide bushing. Figure 15 


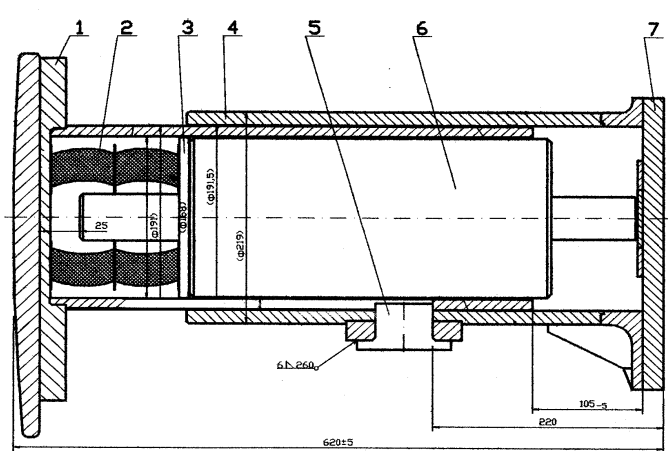

1 - plate; 2 -rubber-metal package; 3 - ring; 4 -outer cylinder; 5 -trigger; 6-elastomeric capsule; 7 -support.

Figure 16

The latter is known in three versions: a small and large hydraulic capsule, metal-rubber package and large hydraulic capsule - Fig. 16, rubber package and large hydraulic capsule.

In order to obtain the indicated features of en ergy absorption, metal foam is used.

The small energy absorption element (i.e. a small hydraulic capsule, rubber package or Belleville spring) provides buffer pre-tensioning and works up to a stroke of 25-30 $\mathrm{mm}$ from the complete deformation of the draw gear. The purpose of this solution is as follows:

(a) According to statistics, $90-95 \%$ of crashes between wagons cause relative displacements in the buffers up to $25 \mathrm{~mm}$. Therefore, in normal operation of railway vehicles, it is only the small energy absorption element that works in practice.

(b) Regulations do not require a relatively gradual increase of force to a stroke of $25 \mathrm{~mm}$ for freight wagons and $30 \mathrm{~mm}$ for passenger carriages and abruptly after the specified values.

In all three variants, the main energy absorption element is the large hydraulic capsule. It operates effectively at significant values of compressive force, providing dissipation of $70-90 \%$ of the accumulated energy under the shock load. The capsule is singlechambered. It is filled with an elastomeric substance with high viscosity and significant compressibility.

The conversion of the impact energy into heat is carried out at the expense of operating fluid throttling with relative displacement of the piston to the capsule body.

There is a trend in railway car manufacturing to apply buffers of " $\mathrm{C}$ " category with "crash" devices for energy absorption. The buffer with "crash" technology acts as a device absorbing much of the impact energy in an irreversible process.

\section{SAMPLE SOLUTIONS FOR PASSENGER CARriage BUFFERS WITH “CRASH” ENERGY ABSORPTION DEVICES}

Two proposals for a buffer of passenger carriages with a "crash" element have been developed:

- with breakable inner and outer bushings;

- with inner "crash" element on tube-in-tube principle.

7.1 Buffer for a passenger carriage with a "crash" element - breakable inner and outer bushings

The proposed design of a buffer with a "crash" element - breakable inner and outer bushings (Fig. 18).

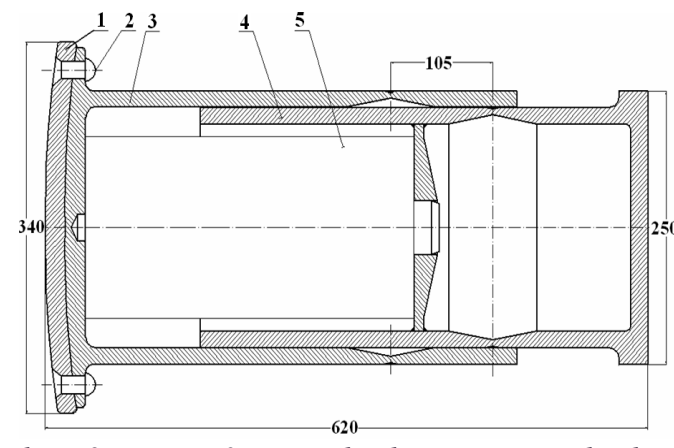

1 -plate; 2 -rivets; 3 -outer bushing; 4-inner bushing; 5 absorption device.

Figure 17: Scheme of a buffer for a passenger carriage with a "crash" element-breakable inner and outer bushings

The structure of the buffer consists of a plate, inner and outer bushings building the casing and an absorber, which can be built of various energy absorption elements.

The proposed casing structure consists of a plate and inner and outer bushings, which are "crash" elements. Upon crash into the buffer, an elastic stroke is performed by the absorber contraction, the stroke being 105 or 110 $\mathrm{mm}$.

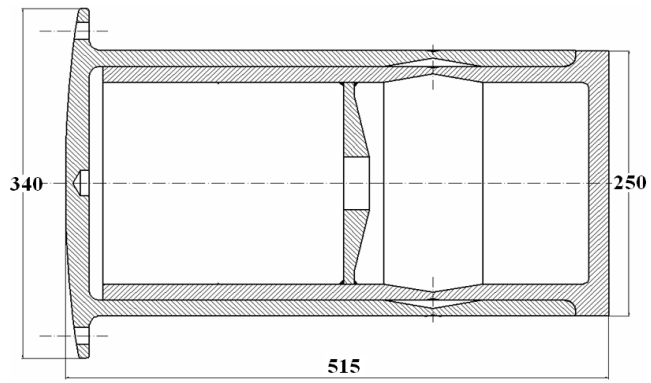

Figure 18: "Crash" elements with exhausting the elastic stroke of $105 \mathrm{~mm}$.

When the elastic stroke is exhausted, the weakened sections of the two bushings coincide and are plastically deformed (Fig. 18).

The proposed structure is a buffer with 7 DURAL packages and "crash" elements.

Technical specifications for the proposed "crash" buffer (Fig. 18): Length: UIC classification: category 6 (UIC 526-1); Reversible spring travel: $105 \mathrm{~mm}$; Energy absorption reversible (dyn.): approx. $40 \mathrm{~kJ}$; Typ. trigger force per buffer: $1500 \mathrm{kN}$; Typ. mean deformation force per buffer: $1112 \mathrm{kN}$; Maximum axial deformation: approx. $200 \mathrm{~mm}$; Total energy absorption capacity per vehicle end (dynamic): approx.600 kJ; Weight per buffer: $127 \mathrm{~kg}$

7.2. Buffer for a passenger car with an inner "crash" element on tube-in-tube principle

The proposed structure of a buffer with an inner "crash" element on tube-in-tube principle (Fig. 19). 


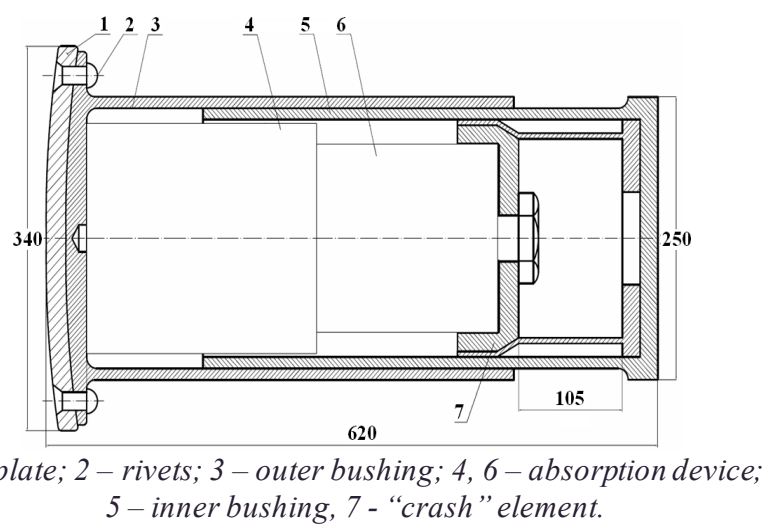

Figure 19: Scheme of a buffer for a passenger carriage with an inner "crash" element on tube-in-tube principle.

The full buffer length does not differ from the typical design. The incomparable advantage of this model is the possibility for block replacement of deformable elements in case of emergency collisions of rail stock with all obstacles. It is assumed that the buffer will work in three stages: Stage 1 - the operation of the first energy absorption element (element with stiffness $\mathrm{k}=44.29$ $\mathrm{N} / \mathrm{mm}$ and a stroke of $25 \mathrm{~mm}$ ).

Stage 1 ensures light crashes of wagons during shunting operations.

Stage 2 -is operation of a set of elastic elements. When the second stage of buffer and absorber operate together, maximum crash absorption is achieved and the smoothest auto-coupler is ensured as a result of shunting operation. In addition, as a result of train movement, the second stage of buffer makes it possible to minimize the negative dynamic accelerations acting on the wagon body.

Stage $3-$ is operation of the buffer in case of collision of railway stock themselves (of wagons with each other) or with any obstacle. As a result, the deformable element, which operates on the principle of a deformation tube, comes into action due to the plastic deformation of metal and maximum crash energy absorption is achieved.

The body of proposed buffer with the elastic stroke exhausted is shown in Fig. 21.

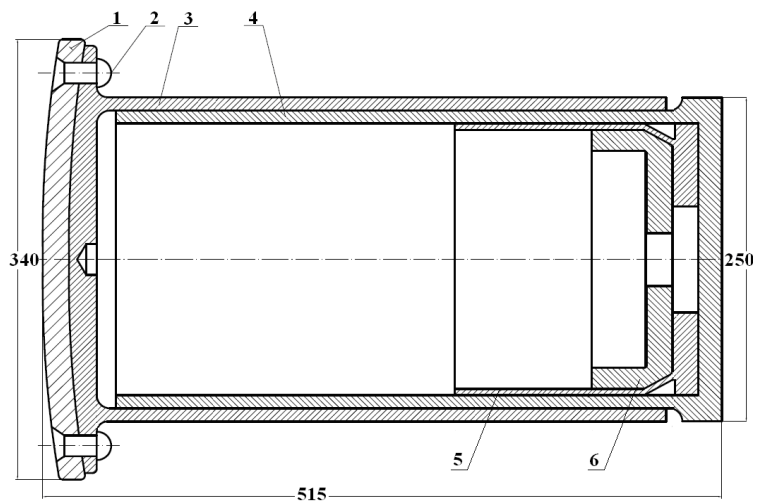

Figure 21: Buffer with inner "crash" element on the tubein-tube principle of when the elastic stroke of $105 \mathrm{~mm}$ is exhausted.

Technical specifications for the proposed "crash" buffer with 7 DUREL packages (Fig.19): Energy absorption reversible (dyn.): approx. $74.09 \mathrm{~kJ}$; Total energy absorption capacity per vehicle end (dynamic): approx. $954 \mathrm{~kJ}$; Weight per buffer: $130 \mathrm{~kg}$.

\section{CONCLUSION}

Based on the presented analysis, the following more important conclusions can be drawn:

1. At present the buffers with rubber-metal packages RMP have the greatest application in BDZ.

2 . From the analysis performed, the buffers with elastomeric capsules can be preferably considered as well as their variants in set with RMP or Belleville spring.

3 . From the analysis made, considering the value of irreversible absorption coefficient and the low value of buffer capsules, in this paper to build-in elastomeric elements of TecsPak or DUREL types in the buffer and draw gear absorber.

4. It is necessary to construct a buffer with "crash" elements. These "crash" elements should be destroyed in a crash between wagons with a shock speed above $12 \mathrm{~km} / \mathrm{h}$ and force $>1.5 \mathrm{MN}$.

5. Two structures for buffers with increased energy absorption and "crash" elements are proposed.

\section{REFERENCES}

[1] 526-1 Wagons - buffers with a stroke of $105 \mathrm{~mm}$, ed.3, July (2008)

[2] UIC 526-2 Wagons - buffers with a stroke of $75 \mathrm{~mm}$ and a stroke of $150 \mathrm{~mm}$, ed.2, October(2008)

[3] UIC 526-3 Wagons - buffers with a stroke of $130 \mathrm{~mm}$ and a stroke of $150 \mathrm{~mm}$, ed.3, October(2008)

[4] Petrovic D., Aleksandrov V., Jeleznicka vozila. Osnove, MF Kraljevo, 2013, ISBN 978-86-82631-66-8 p.223 (2013)

[5] Annual reports on the investigation of railway accident: https://www.mtitc.government.bg

[6] EN 15227-2020 Railway applications Crashworthiness requirements for rail vehicles (2020)

[7] SAFETRAIN project http://www.safetrain.com

[8] Мировой лидер технологий поглощения энергии. http://sdrives.ru>files/Rail-series-brochure-RU.pdf;

[9] ГОСТ 32410-2013 Крэш-системы аварийные железнодорожного подвижного состава для пассажирских перевозок. Технические требования и методы контроля (2013)

[10] Оганьян, Э.С. Критерии несущей способности конструкций локомотивов в экстремальных условиях нагружения: дис. М.: МИИТ, (2004)

[11] FINAL REPORT on the investigation of a railway accident - collision of 19205 passenger train with a car at the guarded level crossing between the stations Krumovo, https://www.mtitc.government.bg (2019)

[12] EN 12663-1:2015, Railway Applications - Structural Requirements of Railway Vehicle Bodies (2015).

[13] CFR Current approach in 49 CFR Part 238 focuses on force resistance of key structural members, 2018

[14] Барышников, А.В. Целесообразность применения устройств поглощения энергии при различных скоростях соударения подвижного состава с препятствием / Наука и техника транспорта. 2019. № 1 C. 78-84. 
[15] ГОСТ 21447-75 Зацепления автосцепки (1975).

[16]ГОСТ 32913-2014 Аппараты поглощающие сцепных и автосцепных устройств железнодорожного подвижного состава. Технические требования и правила приемки.

[17] Perovic D., Dinamika sudara vagona, Biblioteka DISSERTATIO, Beograd,(2001)

[18] Барышников, А. В. Выбор конструкционного решения энергопоглощающего устройства и обоснование его эффективности /Наука и техника транспорта. - № 2 - С. 52-58; (2019)

[19] Азарченков, А.А. Разработка методики оценки аварийной нагруженности пассажирских вагонов при продольных соударениях: дис. ... канд. тех. наук: 05.22.07 / Брянск,-113 c; (2005)

[20] Stoilov V., Slavchev S., Vagoni, Ed. TU-Sofia, 2014, ISBN 978-619-167-135-9, Sofia, 2014, p.222 (2014).

[21] Tests of energy absorption elements for buffers by RTIRT, (2010)

[22] UIC 528 Buffer gear for coaches, ed.8, (2007). 